\title{
Antibody to Galactocerebroside Alters Organization of Oligodendroglial Membrane Sheets in Culture
}

\author{
Charissa A. Dyer and Joyce A. Benjamins \\ Department of Neurology, Wayne State University School of Medicine, Detroit, Michigan 48201
}

\begin{abstract}
Antibodies to galactocerebroside (GalC) cause major changes in the organization of the membrane sheets elaborated by murine oligodendroglia in culture. Exposure of oligodendroglia to rabbit anti-GalC IgG for 15 min followed by fluoresceinated second antibodies results in patches of surface GalC staining; when second antibodies are applied after $\mathbf{2 ~ h r}$ of anti-GalC, the pattern of staining on membrane sheets is solid and wrinkled. Anti-GalC exposure for $\mathbf{2 4} \mathrm{hr}$ results in contracted membrane sheets. No membrane contraction is detected in cultures treated with anti-sulfatide lgM or anti-proteolipid protein IgG. In cultures exposed to antiGalC continuously for 4-7 d, there is a marked decrease in numbers of extended membrane sheets with an accompanying increase in contracted sheets. This effect is reversible upon removal of anti-Galc from the culture media. By scanning electron microscopy, normally flat membrane sheets appear ruffled after $2 \mathrm{hr}$ of anti-GalC treatment; by $24 \mathrm{hr}$, contracted membrane sheets consist entirely of bulbous protrusions. Oligodendrocyte membranes exposed to antisulfatide for $\mathbf{2 4} \mathbf{~ h r}$ are not contracted but are covered with bulbous protrusions. The organization of underlying membrane structures was examined in relation to membrane patching and sheet contraction. In membranes with patching induced by exposure to anti-GalC for $15 \mathrm{~min}$, the anti-GalC: GalC complexes are localized over cytoplasmic MBP domains, with the unstained areas located above cytoplasmic microtubular structures. Membrane sheets that are contracted in response to anti-GalC exposure for 6-24 hr show intense GalC staining over microtubular structures. Anti-GalC exposure does not change metabolism of GalC; in cultures incubated with ${ }^{\mathrm{H}} \mathrm{H}$-galactose and anti-GalC for $\mathbf{2 4} \mathrm{hr}$, there are no alterations in GalC labeling compared with control cultures. In summary, these results provide direct evidence that interaction between surface glycolipids and external antibodies can initiate a sequence of events leading to dramatic changes within the oligodendrocyte.
\end{abstract}

\footnotetext{
Received Jan. 13, 1988; revised Mar. 30, 1988; accepted Apr. 1, 1988.

This research was supported by NIH Grants NS18898 and 13143. We thank Dr. Pamela Knapp and Dr. Robert Skoff for their discussion of the manuscript. We thank Dr. Robert Lazzarini and Dr. Lynn Hudson for providing antiserum to PLP, Dr. Kari Stefansson for donating the monoclonal antibody to sulfatide, and Dr. Said Ghandour for providing antiserum to MBP. We are grateful to Dr. Helene Rauch and Dr. Ilene Montgomery for providing us with Balb/c mice. We greatly appreciate Mr. Hubbert Hill teaching us scanning electron microscopy.

Correspondence should be addressed to Dr. Charissa Dyer, Department of Neurology, 540 E. Canfield Avenue, Wayne State University School of Medicine, Detroit, MI 48201.

Copyright (C) 1988 Society for Neuroscience $0270-6474 / 88 / 114307-12 \$ 02.00 / 0$
}

Onc approach to studying the role of lipids in oligodendroglial membranes and their relationship to membrane and cytoskeletal proteins is through the interactions of specific lipid antibodies with their targets on intact living cells. Cultured murine oligodendroglia with their extensive membrane sheets provide an excellent system in which to study the effects of such antibody interactions. This paper reports the interaction of antibodies with the oligodendroglial membrane lipids, galactocerebroside (GalC) and sulfatide.

Oligodendroglia in mixed glial cultures express several myelin components, including GalC, sulfatide, myelin basic protein (MBP), 2',3'-cyclic nucleotide $3^{\prime}$-phosphodiesterase (CNPase), and proteolipid protein (PLP) (for review, see Pfeiffer, 1984). These oligodendroglia can elaborate processes and membrane sheets, even in the absence of axons (Mirsky et al., 1980; Sarlieve et al., 1980; Szuchet et al., 1980; Barbarese and Pfeiffer, 1981; Bradel and Prince, 1983; Meller and Waelsch, 1984). The distribution of myelin and cytoskeletal components within these processes and membrane sheets has been described (DuboisDalcq et al., 1986; Kachar et al., 1986; Knapp et al., 1987a, b; Reynolds et al., 1987; Dyer and Benjamins, 1988).

We have previously demonstrated that oligodendroglia in culture initially respond to anti-GalC IgG by rapidly internalizing the membrane-bound antibodies and by reorganizing surface GalC into patches in the presence of second antibody (Dyer and Benjamins, 1988). Those findings initiated this series of studies on the effects of antibodies to the oligodendroglial surface components GalC, sulfatide, and PLP. We now report that longterm exposure of oligodendroglia to anti-GalC causes extensive contraction of membrane sheets with accompanying reorganization of the underlying cytoskeleton. In addition, we report that changes occur in the distribution of anti-GalC:GalC complexes upon addition of second antibody after increasing time periods of anti-GalC exposure. To our knowledge, this is the first report of dramatic structural changes induced in oligodendroglia membrane sheets by antibodies directed against surface components.

\section{Materials and Methods}

Oligodendrocyte cultures. Cultures were prepared as described by Dyer and Benjamins (1988) with the following modifications. Briefly, 2- to 4-d-old Balb/c newborn mice were decapitated; their cerebra were removed and sliced into small pieces. The tissue fragments were incubated with $0.25 \%$ tryspin (Difco, Detroit, MI) and $10 \mu \mathrm{g} / \mathrm{ml}$ DNAase (Sigma, St. Louis) in Dulbecco's Modified Eagle's Medium (DMEM; Gibco, Grand Island, NY) plus $6.0 \mathrm{mg} \%$ of glucose for $10 \mathrm{~min}$ at $37^{\circ} \mathrm{C}$. The partially digested tissue was centrifuged and resuspended in DMEM supplemented with $6.0 \mathrm{mg} \%$ glucose, $10 \%$ calf serum, $50 \mu \mathrm{g} / \mathrm{ml}$ streptomyocin, $50 \mu \mathrm{g} / \mathrm{ml}$ penicillin, and $0.15 \mu \mathrm{g} / \mathrm{ml}$ Fungizone. Calf serum was used instead of fetal calf serum since it has been reported to increase 
the yield of oligodendrocytes in culture (Rome et al., 1986). Single cells were obtained by passing the material through the small opening of a Pasteur pipet several times followed by filtering the suspension through a $130 \mu \mathrm{m}$ nitex screen (Tetko, Elmsford, NY). Approximately 8-10 $\times$ $10^{6}$ cells were plated on poly(L-lysine)-coated $75 \mathrm{~cm}^{2}$ tissue culture flasks and grown to confluency. A modification of the method described by Poduslo et al. (1985) was used to shake off the small, dark processbearing cells from the bed layer; flasks were hit sharply on a bench top about 15 times to effectively remove these cells. The cell suspension was filtered through a $33 \mu \mathrm{m}$ nitex screen into an uncoated petri dish and was incubated for $4-6 \mathrm{hr}$ at $37^{\circ} \mathrm{C}$ in $5 \% \mathrm{CO}_{2}$ to remove adherent flat cells (Suzumura et al., 1984). The remaining round floating cells were plated on $15 \mathrm{~mm}$ poly(L-lysine)-coated coverslips (approximately 100,000 cells/coverslip) or in $25 \mathrm{~cm}^{2}$ poly(L-lysine)-coated flasks (about $1 \times 10^{6}$ cells/flask). Cultures were grown in medium made by mixing 2 vol of chemically defined medium (Bottenstein, 1986) with 1 vol of DMEM containing $10 \%$ calf serum, so that the final concentration of calf serum was $3.3 \%$. The medium was completely changed every 3-4 d. Cultures were used in experiments after 22-24 d in vitro.

Antibodies. Polyclonal anti-GalC was produced in rabbits and characterized according to Benjamins et al. (1987). The IgG fraction was isolated using a protein A-Sepharose column, lyophilized, and then dialyzed against DMEM plus antibiotics as described in Dyer and Benjamins (1988). Protein content was determined by the Biorad assay using rabbit (RIgG) as standard. The antibody specificity was determined in an ELISA; the IgG fraction reacted strongly with GalC and only weakly with psychosine. At the 1:16 dilution used in these experiments, the IgG fraction did not react significantly with sulfatide.

Polyclonal antiserum reactive with PLP was generously donated by Dr. Robert Lazzarini and Dr. Lynn Hudson. The antiserum was produced in rabbits against a synthetic peptide corresponding to the 109128 sequence of the PLP molecule. IgG antibodies were isolated from the serum as previously described for the anti-GalC antibodies. The IgG fraction was then incubated with a PLP affinity column overnight at $4^{\circ} \mathrm{C}$ with constant mixing. The unbound material was washed through the column with TBS, $\mathrm{pH} 7.4$. The remaining bound antibodies were eluted with $0.2 \mathrm{M}$ glycine, $\mathrm{pH} 2.3$, and neutralized with $0.5 \mathrm{M}$ Tris, $\mathrm{pH}$ 8.5. The affinity-purified antibodies were lyophilized and dialyzed against DMEM plus antibiotics.

Monoclonal antibody to sulfatide (IgM) was donated by Dr. Kari Stefansson. The specificity and titer of the monoclonal antibody was tested by ELISA (Benjamins et al., 1987). At dilutions of 1:50 and 1:200, the monoclonal antibody reacted with sulfatide but not with GalC, psychosine, glucocerebroside, mixed gangliosides, monogalactosyl diglyceride, or digalactosyl diglyceride.

Rabbit anti-MBP serum was a gift from Dr. Said Ghandour. By immunoblot analysis, this serum was shown to react strongly with MBP in myelin. When tested on blots containing proteins from a bovine spinal cord cytoskeletal fraction, the serum also reacted to some extent with 2 bands in the region of glial fibrillary acidic protein.

Nonspecific RIgG was isolated from rabbit bleeds taken prior to immunization with GalC and was purified by passage through a protein A-Sepharose column as described above.

Monoclonal IgG against $\alpha$ - and $\beta$-tubulin was obtained from BioGenex Laboratories (Dublin, CA).

Immunofluorescent staining. Shakeoff cultures grown on coverslips were continuously exposed to antibodies directed against either GalC, PLP, or sulfatide for time periods as long as $7 \mathrm{~d}$. Control cultures were treated with nonspecific RIgG for equivalent periods of time. Cells were exposed to $590 \mu \mathrm{g} / \mathrm{ml}$ of anti-GalC IgG, $25 \mu \mathrm{g} / \mathrm{ml}$ affinity-purified antiPLP IgG, or $590 \mu \mathrm{g} / \mathrm{ml}$ nonspecific RIgG. This amount of anti-GalC IgG was equivalent to a 1:16 dilution of the original polyclonal serum. A 1:4 dilution of the anti-sulfatide hybridoma supernatant was determined by ELISA to have a titer approximately equivalent to $590 \mu \mathrm{g} /$ $\mathrm{ml}$ of anti-GalC IgG. After exposure to a primary antibody, cells were washed and stained for $15 \mathrm{~min}$ at $37^{\circ} \mathrm{C}$ with a $1: 40$ dilution of an appropriate second antibody. The second antibodies used were goat anti-rabbit IgG (GAR), goat anti-mouse IgG (GAM), or goat anti-mouse IgM, each tagged with either fluorescein (FITC) or rhodamine (TRITC) (Cooper Biomedical, Malvern, PA). For identification of oligodendrocytes in control cultures or cultures incubated with anti-PLP, anti-GalC was added for an additional $15 \mathrm{~min}$ followed by GAR IgG-FITC for 15 min at $37^{\circ} \mathrm{C}$. Cells were fixed with $4 \%$ formaldehyde in PBS for 5$10 \mathrm{~min}$ and mounted with Aquamount on a glass slide.

Cultures double-labeled for GalC and tubulin were sequentially treat- ed with anti-GalC (1:16) and GAR-FITC (1:40). Cells were fixed, treated with saponin, and stained with anti-tubulin (1:100) and GAM-TRITC (anti-heavy chain; $1: 40$ ).

Cells labeled for both MBP and tubulin were fixed and saponin-treated prior to labeling. Polyclonal anti-MBP (1:100) and GAR-FITC (1:40) were added followed by anti-tubulin IgG (1:100) and GAM-TRITC (1: 40).

All preparations were viewed on a Leitz Laborlux 12 microscope equipped with appropriate filters for rhodamine and fluorescein optics and were photographed with 400 ASA film.

Scanning electron microscopy (SEM). Cells were treated with rabbit anti-GalC IgG or mouse anti-sulfatide IgM continuously for $24 \mathrm{hr}$ at $37^{\circ} \mathrm{C}$. Cultures were washed and fixed in $4 \%$ formaldehyde for $5 \mathrm{~min}$ followed by GAR IgG conjugated to $40 \mathrm{~nm}$ gold particles (1:2) or GAM IgM conjugated to $40 \mathrm{~nm}$ gold particles (1:2) (Jansen, Piscataway, NJ), respectively, for $1 \mathrm{hr}$ at room temperature. The cells were fixed in $5 \%$ glutaraldehyde in PBS for 10 min followed by a water wash. Coverslips were then immersed in Freon 22 followed by liquid nitrogen and were dried overnight in an Edwards lyophilizer (Sussex, England). The freezedried cells were coated with gold in a Hummer X (Anatech, LTD, Alexandria, VA) and scanned with an Etech Autoscanning Microscope at $30 \mathrm{kV}$ at a working distance of approximately $11 \mathrm{~mm}$.

Metabolic studies. Shakeoff cultures grown in $25 \mathrm{~cm}^{2}$ tissue culture flasks were treated with $100 \mathrm{uCi} /$ flask ${ }^{3} \mathrm{H}$-galactose $(25 \mathrm{Ci} / \mathrm{mmol}$; ICN, Irvine, CA) and either anti-GalC IgG or nonspecific RIgG for $24 \mathrm{hr}$. Another group of cultures was treated with either anti-GalC or RIgG for $72 \mathrm{hr}$ and were pulsed with $100 \mu \mathrm{Ci} /$ flask ${ }^{3} \mathrm{H}$-galactose during the final $24 \mathrm{hr}$ of the antibody exposure period. Before trypsinization, cells were washed 3 times with PBS $\left(\mathrm{Ca}^{2+}, \mathrm{Mg}^{2+}\right.$ free; Gibco, Grand Island, NY). Cells were detached from the flasks after incubation for $10 \mathrm{~min}$ at $37^{\circ} \mathrm{C}$ in trypsin solution $(0.02 \%$ trypsin, $0.02 \%$ EDTA in PBS which was $\mathrm{Ca}^{2+}$ and $\mathrm{Mg}^{2+}$ free). The trypsinized cells were mixed with $5 \mathrm{ml}$ of DMEM plus $10 \%$ calf serum and centrifuged, and the pellets were washed 3 times in PBS. Protein determinations (Lowry et al., 1951) with BSA as standard were performed on one-tenth of the suspended cell pellet. Lipid extractions (Folch et al., 1957) followed by alkaline methanolysis (Kishimoto and Radin, 1965) were performed on the remaining material. The alkali-stable lipids were run on TLC plates and detected by iodine vapors; the GalC bands were scraped from the plates and counted.

\section{Results}

Antibodies to GalC and sulfatide hut not proteolipid protein cause morphologic changes in oligodendroglial membrane sheets

The continuous presence of anti-GalC in murine glial shake-off cultures caused dramatic contraction and alteration in the appearance of oligodendroglial membrane sheets. Short-term exposure to anti-GalC IgG for $15 \mathrm{~min}$ followed by second antibody for $15 \mathrm{~min}$ at $37^{\circ} \mathrm{C}$ resulted in a patchy staining pattern on oligodendrocyte membrane sheets (Fig. 1a). However, patching was rarely observed after continued exposure to anti-GalC IgG for $2 \mathrm{hr}$ followed by GAR-FITC for $15 \mathrm{~min}$ at $37^{\circ} \mathrm{C}$. Instead, under these conditions most membrane sheets were solidly stained, and some appeared contracted and wrinkled (Fig. $1 b$ ). After 1-2 d of continuous exposure to anti-GalC IgG followed by $15 \mathrm{~min}$ of GAR-FITC, many sheets were wrinkled while others had a mottled appearance (Fig. 1 c). The majority of membrane sheets were condensed into wrinkled masses after $7 \mathrm{~d}$ of continuous exposure to anti-GalC IgG and $15 \mathrm{~min}$ of GARFITC (Fig. 1d). Therefore, it appears that a progressive series of changes occurred in these sheets; patchy staining changed to solid staining with increasing membrane contraction. These effects were apparent on most membrane sheets after $2 \mathrm{~d}$ of exposure to anti-GalC.

We have previously demonstrated that following a $15 \mathrm{~min}$ exposure to anti-GalC, patches of fluorescence on oligodendro- 

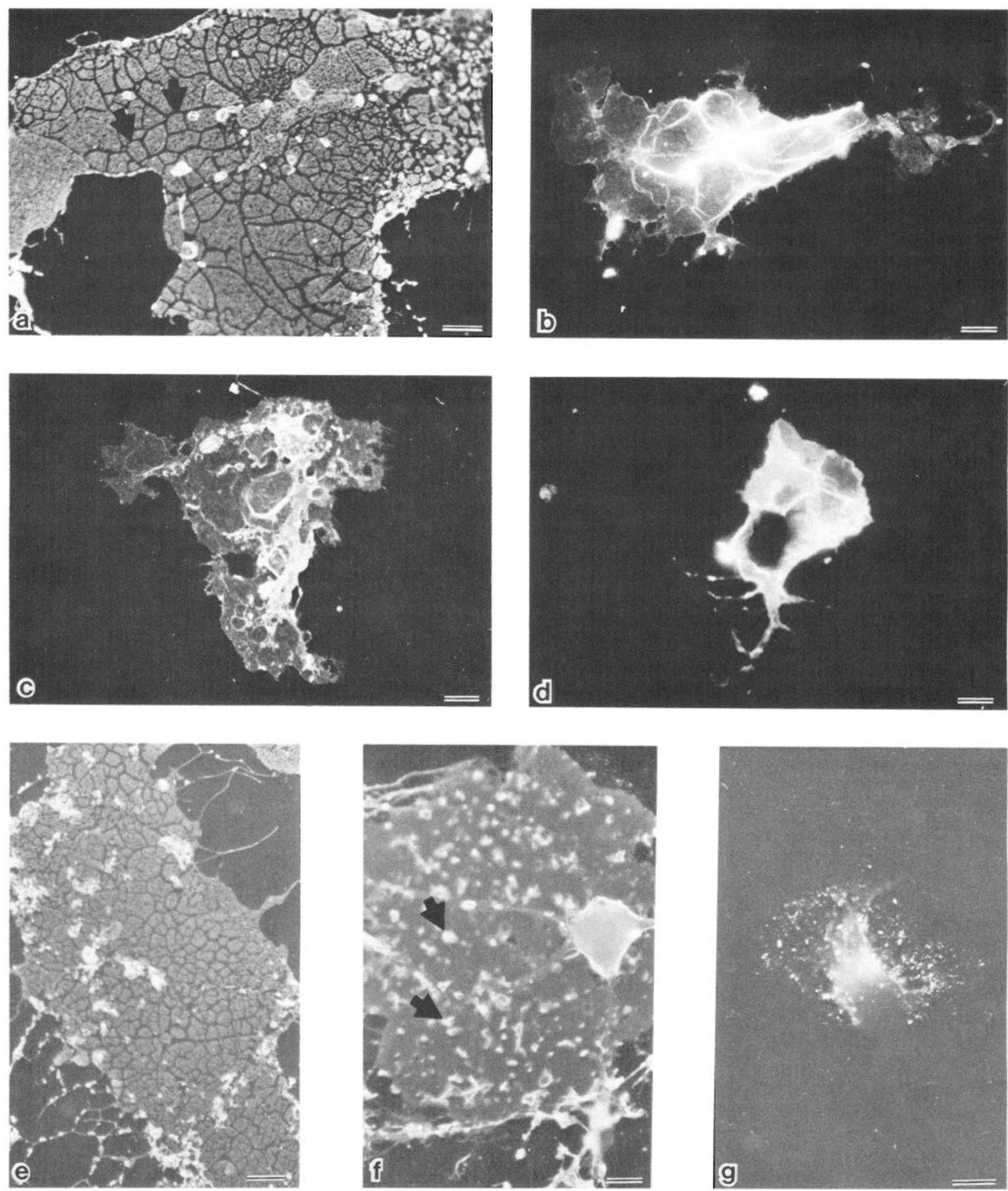

Figure 1. Morphologic changes in oligodendroglial membrane sheets after continuous exposure to anti-GalC and anti-sulfatide. $a$, Patches of GalC (arrows) on oligodendrocyte following incubation with anti-GalC for $15 \mathrm{~min}$ and GAR-FITC for $15 \mathrm{~min}$. $b$, Condensed, wrinkled membrane sheet in culture exposed to anti-GalC for $2 \mathrm{hr}$ and GAR-FITC for $15 \mathrm{~min}$. $c$, Wrinkled surface of oligodendrocyte culture exposed to anti-GalC for 24 $\mathrm{hr}$ and GAR-FITC for $15 \mathrm{~min}$. $d$, Wrinkled mass of oligodendroglial membrane sheet in culture exposed continuously to anti-GalC for $7 \mathrm{~d}$ and GAR-FITC for $15 \mathrm{~min} . e$, Patchy surface staining on oligodendrocyte following exposure to anti-sulfatide for $15 \mathrm{~min}$ and GAM-FITC for 15 min. $f$, Bright rings of staining (arrows) on solidly stained membrane sheets exposed to anti-sulfatide for $2 \mathrm{~d}$ and GAM-FITC for 15 min. $g$, Punctate PLP surface staining of oligodendroglia exposed to anti-PLP for $15 \mathrm{~min}$ and GAR-FITC for $15 \mathrm{~min}$. Scale bars, $15 \mu \mathrm{m}$. 


\section{EFFECTS OF ANTI-GALC ON MEMBRANE SHEETS ARE REVERSIBLE}

Figure 2. Reversible effects of antiGalC on membrane sheets. Cultures were incubated continuously with either $\mathrm{RIgG}$ or anti-GalC for $7 \mathrm{~d}$ and were compared with cultures treated with anti-GalC for $4 \mathrm{~d}$ followed by RIgG for $3 \mathrm{~d}$. Data are shown with ranges for duplicate coverslips. Each coverslip had approximately $1000 \mathrm{GalC}$-positive cells.

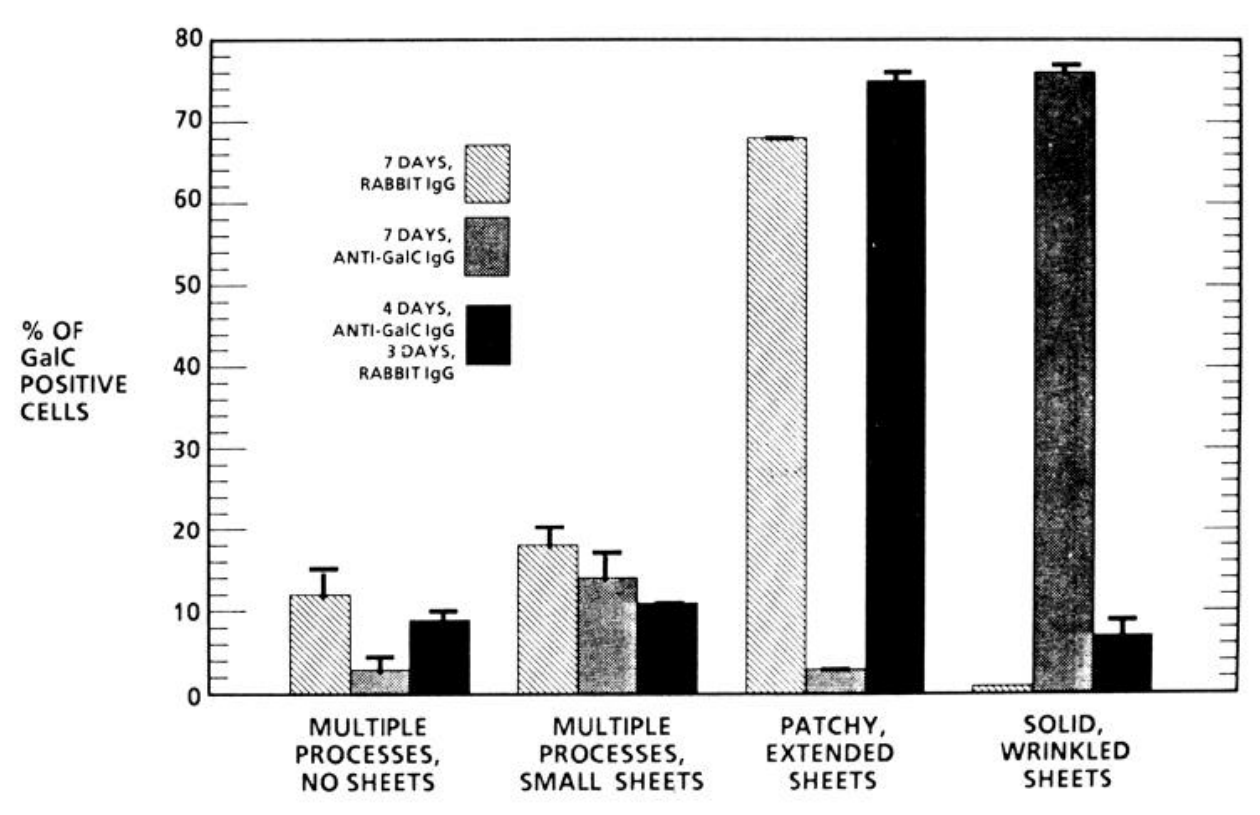

cyte membranes are induced by cross-linking of the anti-GalC: GalC complexes by second antibody (Dyer and Benjamins, 1988). The changes we report here represent the effects of exposure to anti-GalC for varying times followed by exposure to second antibody for $15 \mathrm{~min}$. Preliminary results from the present longterm studies show that, while second antibody is necessary for patching after short-term exposure to anti-GalC, patching can occur slowly in the absence of second antibody since anti-GalC alone can induce patching after $2 \mathrm{hr}$. These results suggest that second antibody is accelerating the reorganization of GalC initiated by anti-GalC.

Exposure to anti-sulfatide IgM caused changes in distribution of sulfatide on oligodendroglial membranes similar to those described above for GalC in the presence of anti-GalC. Shortterm exposure to anti-sulfatide IgM for $15 \mathrm{~min}$ followed by 15 min of second antibody resulted in patches of fluorescence on oligodendrocyte membrane sheets (Fig. 1e). As observed in antiGalC-treated cultures, solid staining with interspersed brightly stained rings was observed after $2 \mathrm{~d}$ of continuous exposure to anti-sulfatide and $15 \mathrm{~min}$ of second antibody (Fig. $1 \mathrm{f}$ ). However, membrane contraction was not observed, in contrast to the results in anti-GalC-treated cultures.

Oligodendroglia exposed to anti-PLP IgG or to nonspecific RIgG did not exhibit detectable changes in membrane morphology or surface staining patterns. PLP surface staining of mouse oligodendrocytes was faint and punctate both initially and after $2 \mathrm{~d}$ of exposure to anti-PLP (Fig. $1 \mathrm{~g}$ ). For visualization of these sheets, cells were exposed to anti-GalC for $15 \mathrm{~min}$ and GAR-FITC for $15 \mathrm{~min}$. Oligodendrocyte membrane sheets exposed to anti-PLP for $2 \mathrm{~d}$ (not shown) were still extended and exhibited patchy GalC staining identical to that seen in control cultures exposed to nonspecific RIgG for $2 \mathrm{~d}$. Thus, the organization of oligodendroglial membranes was altered after longterm exposure to anti-GalC or anti-sulfatide as demonstrated by a lack of surface patching; this effect was not observed after long-term exposure to anti-PLP.

\section{Quantitation and reversibility of morphologic changes of oligodendrocyte membrane sheets resulting from anti-GalC IgG exposure}

Morphologic changes were quantitated by counting GalC-positive cells on coverslips under a fluorescent microscope following treatment with either RIgG for $7 \mathrm{~d}$, anti-GalC for $7 \mathrm{~d}$, or anti-GalC for $4 \mathrm{~d}$ followed by RIgG for $3 \mathrm{~d}$ (Fig. 2). GalCpositive cells were assigned to 1 of 4 categories: (1) multiple processes with no sheets, (2) multiple processes with small flat sheets less than approximately $20 \mu \mathrm{m}$ in diameter, (3) patchy extended sheets, and (4) solidly stained and wrinkled contracted sheets. Anti-GalC IgG significantly decreased the numbers of oligodendrocytes with extended patchy sheets and increased the numbers with contracted, solidly stained sheets, while the numbers of oligodendrocytes in the other 2 categories remained relatively unchanged. Specifically, the percentage of GalC-positive cells with patchy extended sheets in control cultures treated with RIgG for $7 \mathrm{~d}$ was $68 \%$ but accounted for only $3 \%$ in cultures treated for $7 \mathrm{~d}$ with anti-GalC IgG. This decrease in patchy extended sheets was balanced by a dramatic rise in the numbers of GalC-positive cells with solidly stained, contracted sheets, which rose from $1 \%$ in control cultures to $76 \%$ in $7 \mathrm{~d}$ anti-GalC treated cultures. A remarkable recovery was observed if cells were incubated for $4 \mathrm{~d}$ with anti-GalC and then with RIgG for an additional $3 \mathrm{~d}$. The percentage of GalC-positive cells with patchy extended sheets was similar to that in controls, about $75 \%$, although approximately one-third of the cells in this category still showed some wrinkling at the cell bodies. In addition, a concomitant drop in the numbers of GalC-positive cells with solidly stained, contracted sheets to the control level of $5 \%$ was observed. The observation that the morphologic changes were reversible and the fact that the total number of GalC-positive cells remained constant (approximately 1000/coverslip) for each of the 3 experimental conditions support the conclusion that $\mathrm{GalC} \mathrm{IgG} \mathrm{was} \mathrm{not} \mathrm{killing} \mathrm{GalC-positive} \mathrm{cells.} \mathrm{Thus,} \mathrm{the} \mathrm{presence}$ 
of anti-GalC caused morphologic alterations in a large majority of the oligodendrocytes, and upon removal of antibody, the morphology of these altered cells returned to normal.

\section{SEM of oligodendroglia treated with anti-GalC and anti-sulfatide}

SEM was used to investigate further the alterations induced in oligodendroglial membranes by the anti-glycolipid antibodies. Cultures were continuously exposed to anti-GalC IgG or antisulfatide IgM for $24 \mathrm{hr}$ and were prepared for SEM as described in Materials and Methods. Colloidal gold-conjugated second antibodies were used to tag anti-GalC IgG:GalC complexes, thus identifying oligodendrocytes. Normal oligodendrocytes had relatively smooth, flat membrane sheets (Fig. $3 a$ ). After treatment with anti-GalC IgG for $2 \mathrm{hr}$, ruffling and blebbing of oligodendroglial membrane sheets and cell bodies were observed (Fig. $3 b$ ). This cell was identified as an oligodendrocyte by the presence of colloidal gold particles on its surface (Fig. 3c). The membrane of a neighboring cell (possibly an astrocyte) was not ruffled (Fig. 3d). Colloidal gold particles were not observed on its membrane (Fig. 3e), and it was unaltered by the presence of anti-GalC in the medium, as found for all GalC-negative cells. Treatment with anti-GalC for $6 \mathrm{hr}$ resulted in more extensive ruffling of entire oligodendrocyte membranes (not shown). After $24 \mathrm{hr}$ of anti-GalC exposure, the surface of membrane sheets and cell bodies consisted entirely of bulbous protrusions (Fig. $3, f, g)$.

Anti-sulfatide IgM antibodies produced similar changes on the surface of oligodendroglial membranes as observed by SEM. Colloidal gold second antibodies were used for specifically identifying oligodendrocytes, and, as with anti-GalC treated cultures, only sulfatide-positive cells and associated membranes exhibited morphologic changes as a result of exposure to anti-sulfatide IgM. After a $2 \mathrm{hr}$ treatment with anti-sulfatide, membrane sheets were relatively flat with scattered bulbous protrusions on their surfaces (Fig. 3h); these membrane projections may correspond to the brightly stained rings seen by immunofluorescence (Fig. 1f). After $6 \mathrm{hr}$, membrane sheets were still extended, but greater numbers of bulbous protrusions were present (not shown). As shown in Figure 3i, membrane sheets were not contracted even after a $24 \mathrm{hr}$ exposure of anti-sulfatide. However, the surface of cell bodies and membrane sheets were composed of bulbous protrusions (Fig. 3,i,j). Thus, both anti-GalC and anti-sulfatide induced dramatic changes on the surface of oligodendroglial membranes within a $24 \mathrm{hr}$ period, but membrane contraction was observed only when cultures were exposed to anti-GalC.

\section{Relationship between patching of antibody:GalC complexes and distribution of microtubules and myelin basic protein $(M B P)$}

Since cell membranes are intricately linked to their underlying cytoskeletons, it was of interest to study changes occurring in the cytoskeletal structure of oligodendrocytes coincident with changes in surfacc appcarancc and sizc after treatment with antiGalC IgG. We first examined whether patching of anti-GalC: GalC complexes on oligodendroglial membrane sheets was accompanied by changes in the organization of microtubules. Under normal culture conditions, when cells were fixed and permeabilized with saponin, staining with anti-tubulin revealed lacy networks of microtubular structures in oligodendroglial membrane sheets (Fig. 4a). Control experiments were performed to determine whether internalization of anti-GalC or presence of second antibody altered tubulin staining. First, when cells were exposed to anti-GalC for $15 \mathrm{~min}$ to $2 \mathrm{hr}$ to allow internalization, then fixed, permeabilized, and stained for tubulin, the microtubular structures were identical to those seen in cultures shown in Figure $4 a$. Next, the effect of adding second antibody to the surface anti-GalC:GalC complexes was examined. Cultures were exposed to anti-GalC alone for $15 \mathrm{~min}$ and then fixed before addition of second antibody so that patching did not occur. Under these conditions, sheets were solidly stained for surface GalC (Dyer and Benjamins, 1988) and the microtubule structures were identical to those seen in control cultures not exposed to anti-GalC. Thus, neither internalization of anti-GalC nor the labeling of GalC per se with anti-GalC and GAR-FITC altered the internal microtubular structures or interfered with their detection.

Patching of anti-GalC:GalC complexes was induced on oligodendroglial membrane sheets by exposure of cultures to antiGalC IgG for $15 \mathrm{~min}$ followed by GAR-FITC for $15 \mathrm{~min}$. When these cultures were double-stained for GalC and tubulin, we observed that the patches of GalC staining were separated by negatively stained areas coincident with the network of microtubular structures (Fig. $4, b, c$ ). There appeared to be fewer microtubular structures after patching occurred; many of the thin filaments in the network had disappeared. These observations indicate that cytoskeletal changes appear to be associated with patching of anti-GalC:GalC complexes on oligodendroglial membrane sheets.

Since MBP is a prominent protein on the cytoplasmic face of oligodendroglial membranes, it was of interest to determine its spatial relationship with microtubules. For examination of MBP distribution, cells were fixed, permcabilizcd, and double-labeled for tubulin and MBP. MBP staining in normal oligodendroglia was clearly present in areas between microtubular structures (Fig. $4, d, e$ ), as were $\mathrm{GalC}$ patches in oligodendroglia treated with anti-GalC and second antibody (Fig. $4, b, c$ ). Thus, an association appears to exist between MBP domains on the cytoplasmic face of membrane sheets and patched antibody:GalC complexes on the external layer of membrane sheets, and these domains are demarcated by microtubular structures. We do not yet know whether patching causes changes in distribution of MBP.

\section{Relationship between tubulin distribution and surface GalC following long-term exposure to anti-GalC}

Exposure to anti-GalC IgG for $6 \mathrm{hr}$ or longer altered the distribution of both surface $\mathrm{GalC}$ and microtubular structures (Fig. $5, a, c)$. Areas over microtubular structures were now intensely stained for GalC, whereas there had been no correspondence between patterns of microtubule staining and surface GalC staining after a brief exposure to anti-GalC IgG (Fig. 4, $b, c$ ). Solid GalC staining was present in between these brightly stained tracts. The extensive surface mottling and contraction of membrane sheets in these oligodendrocytes was accompanied by massive reorganization of microtubular structures (Fig. 5, $b, d$ ). Tubulin staining was very intense at cell bodies and along major veinlike structures in sheets. The greatest concentrations of surface antibody:GalC complexes in the membranes were located directly above these intensely labeled microtubular structures.

After 10-24 hr of exposure to anti-GalC IgG, changes in oligodendroglial membrane surfaces and internal microtubular structures were more pronounced than at $6 \mathrm{hr}$ (Fig. 5, $e, f$ ). Bright GalC-containing rings with underlying microtubular 

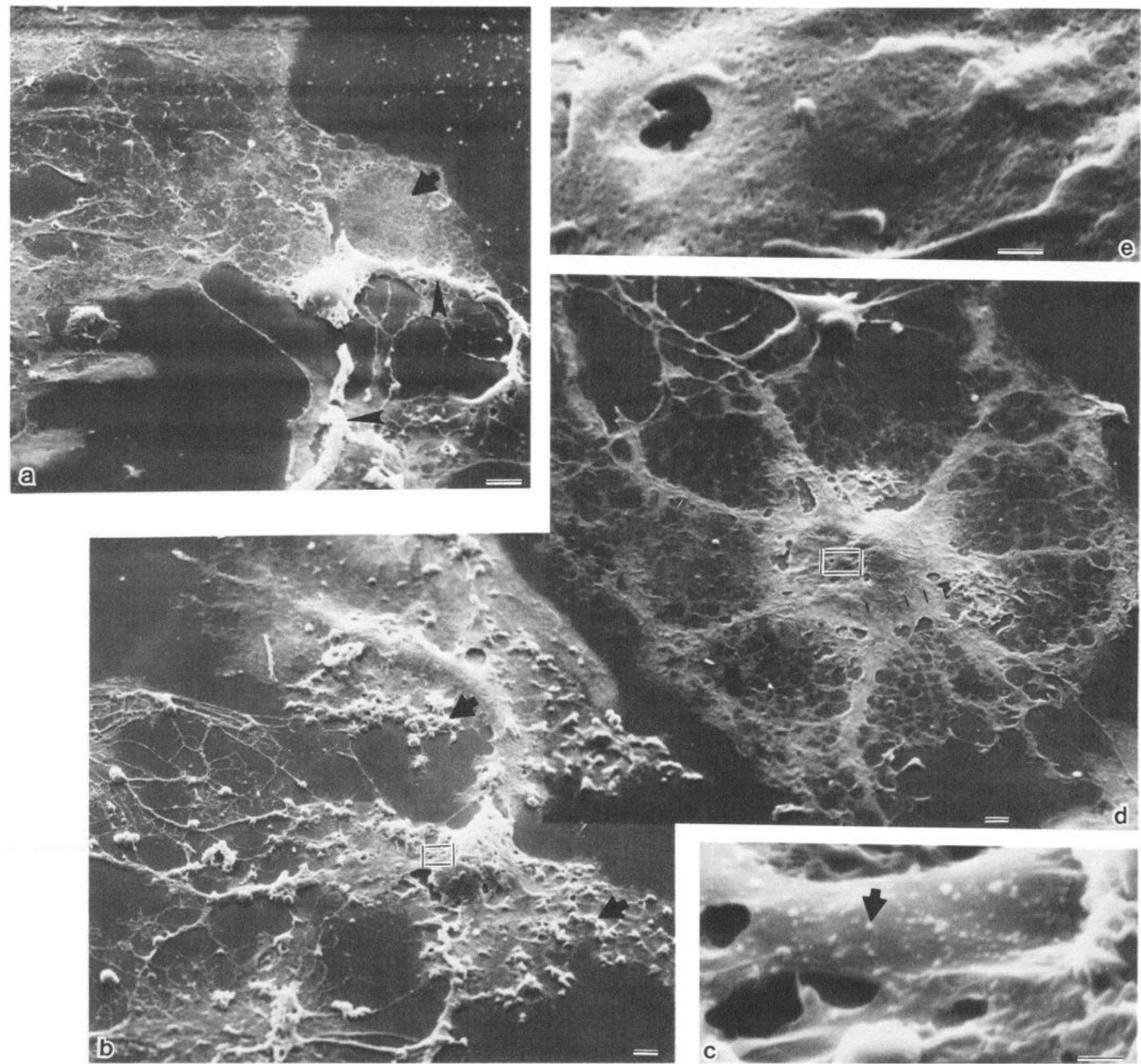

Figure 3. Scanning electron microscopy (SEM) demonstrating morphologic changes on oligodendroglial membrane sheets during a 24 hr exposure to anti-GalC and anti-sulfatide. $a$, Representative normal oligodendrocyte with flat, expansive membrane sheet (arrow) and large processes (arrowheads) extending from the cell body. Scale bar, $10 \mu \mathrm{m} . \times 900 . b$, Ruffling of oligodendrocyte membrane sheet (arrows) and cell body after a 2 $\mathrm{hr}$ continuous exposure to anti-GalC. Scale bar, $5 \mu \mathrm{m}$. $\times 680$. $c$, Higher magnification of boxed area on membrane sheet shown in $b$, with arrow pointing to one of many colloidal gold particles. Scale bar, $0.5 \mu \mathrm{m} . \times 16,900 . d$, No ruffling is observed on this cell membrane (possibly an astrocyte), which is adjacent to the oligodendrocyte shown in $b$. Scale bar, $5 \mu \mathrm{m}$. $\times 900$. $e$, Higher magnification of boxed area shown in $d$ demonstrates the lack of colloidal gold particles on this cell. Scale bar, $0.5 \mu \mathrm{m} . \times 16,900 . f$, Representative oligodendroglial membrane composed entirely of bulbous protrusions $24 \mathrm{hr}$ after continuous exposure to anti-GalC. Scale bar, $20 \mu \mathrm{m}$. $\times 290 . \mathrm{g}$, High magnification of boxed area in $f$. Scale bar, $2 \mu \mathrm{m}$.

structures were present on many oligodendrocytes; these structures may correspond to the bulbous protrusions seen by SEM (Fig. $3 f$ ). Also, the lacy tubulin network was detected only on the edges of contracted sheets instead of throughout entire membrane sheets as observed in control cells. Tubulin was brilliantly stained along large veinlike structures radiating from intensely stained cell bodies; the intensely stained microtubular structures were beneath areas of membrane intensely stained for surface GalC. Thus, after long-term exposure to anti-GalC, an associ- ation appears to have formed between surface antibody:GalC complexes and internal microtubular structures.

\section{Incorporation of ${ }^{3} \mathrm{H}$-galactose into galactose unaltered after treatment with anti-GalC}

Previous studies in myelinating organ cultures have reported increased synthesis of GalC after exposure to anti-white matter serum (Lehrer et al., 1979). These reported results and our observations of dramatic changes in oligodendroglial morphology 

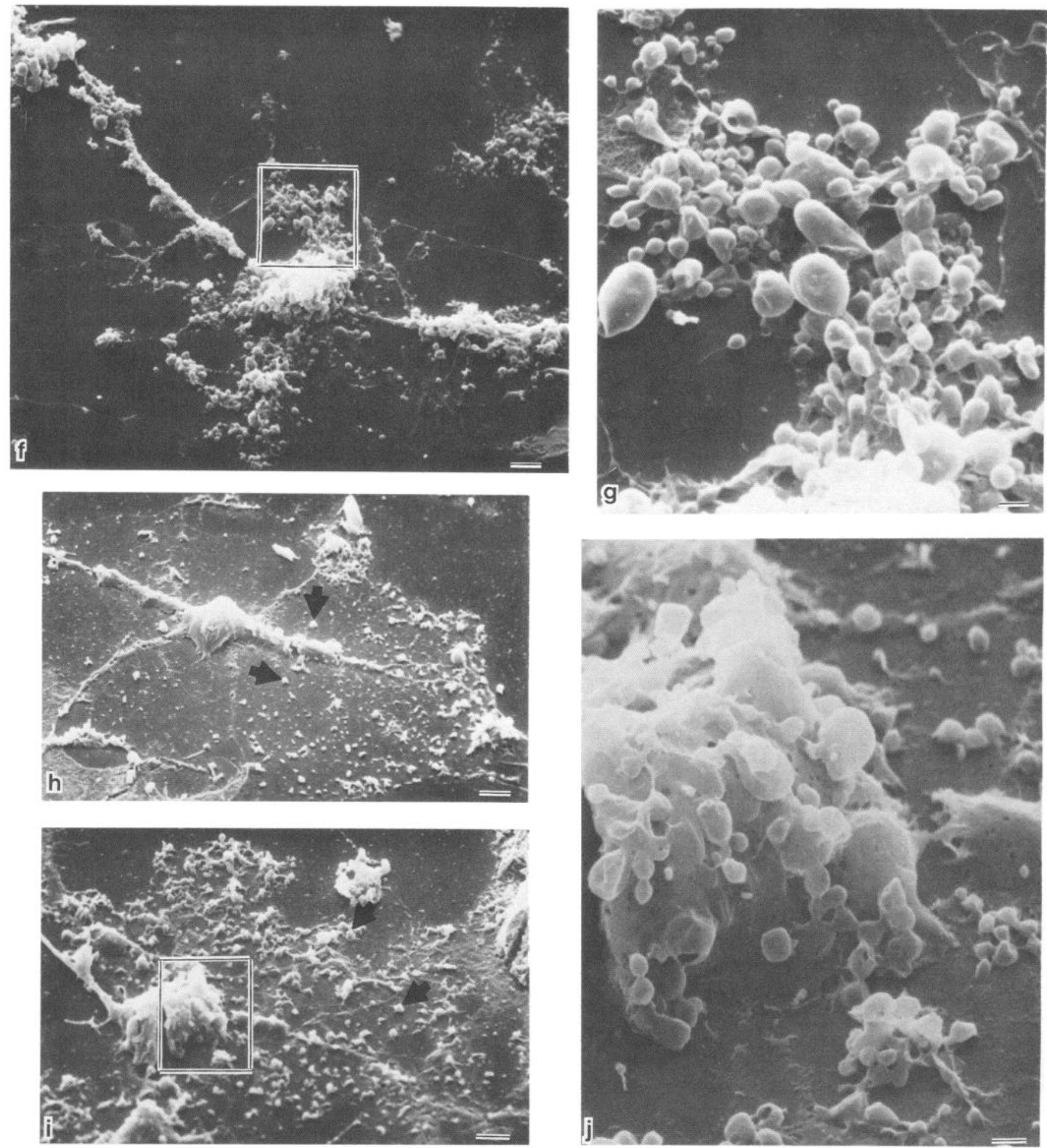

$\times 2900$. $h$, Bulbous protrusions (arrows) on extended sheets in cultures exposed to anti-sulfatide for $2 \mathrm{hr}$. Scale bar, $10 \mu \mathrm{m}$. $\times 600 . i$, Representative oligodendrocyte with many bulbous protrusions (arrows) scattered over the entire extended membrane surface following $24 \mathrm{hr}$ exposure to antisulfatide. Scale bar, $10 \mu \mathrm{m}$. $\times 650 . j$, Higher magnification of boxed area in $i$. Scale bar, $2 \mu \mathrm{m} . \times 3300$.

led us to investigate whether GalC synthesis was perturbed after anti-GalC IgG exposure. Approximately $1 \times 10^{6}$ cells in $25 \mathrm{~cm}^{2}$ flasks were exposed to anti-GalC and to ${ }^{3} \mathrm{H}$-galactose for $24 \mathrm{hr}$. $\mathrm{GalC}$ was isolated as described in Materials and Methods. No significant change in GalC synthesis was observed compared with controls after a $24 \mathrm{hr}$ treatment with anti-GalC IgG (Table
1). Only very low levels of radioactive GalC were detected in the tissue culture medium when the $24 \mathrm{hr}$ experiments were terminated, indicating that $\mathrm{GalC}$ was not being shed from the treated oligodendrocytes in significant amounts (data not shown). Effects of longer exposure to anti-GalC were examined by exposing cultures to anti-GalC for $72 \mathrm{hr}$ with ${ }^{3} \mathrm{H}$-galactose present 

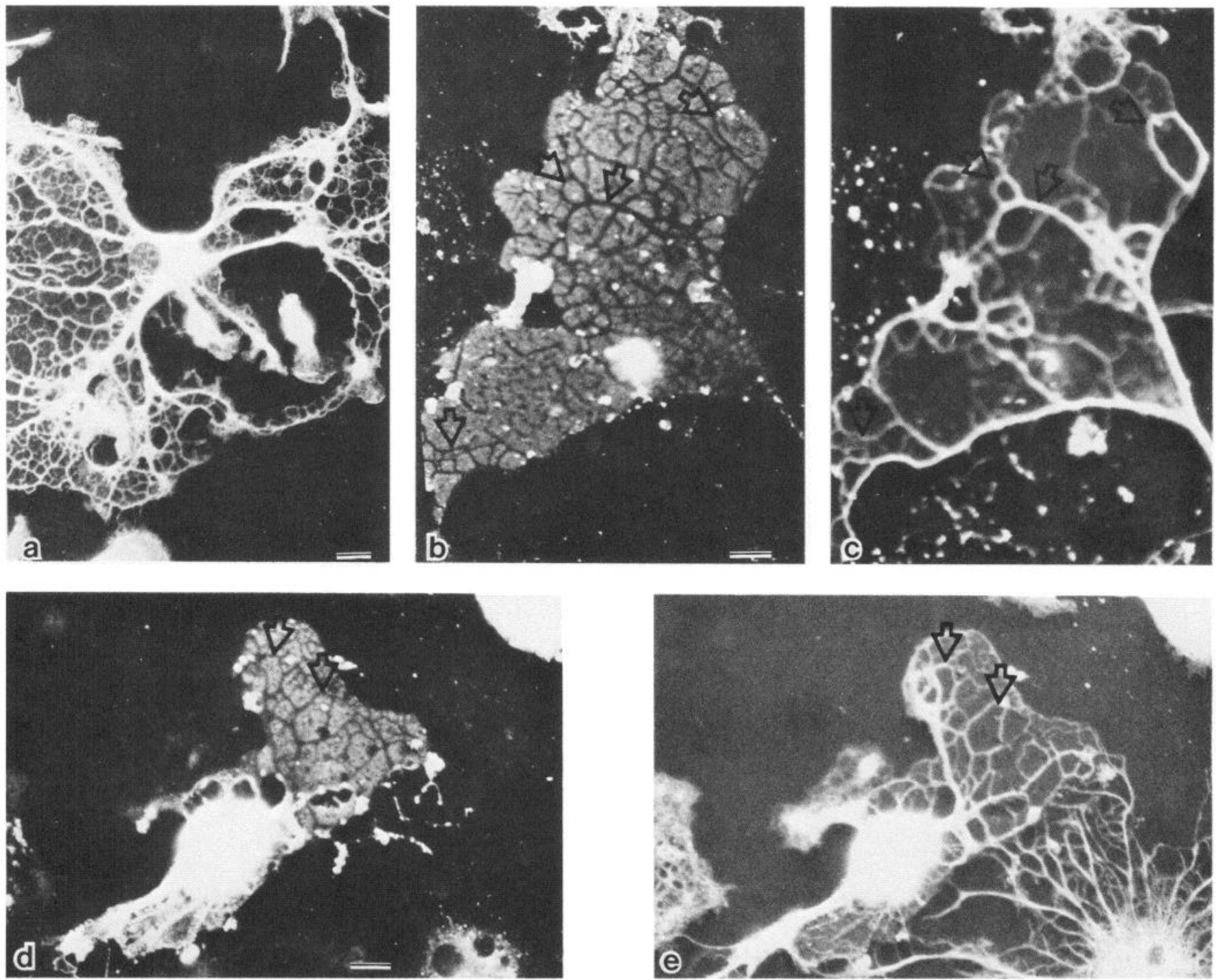

Figure 4. Relationship of surface GalC patches to internal MBP domains and microtubular structures. $a$, Representative oligodendrocyte stained for tubulin after fixation and saponin treatment. $b$, Patched GalC surface staining on membrane sheet following exposure to anti-GalC for 15 min and GAR-FITC for $15 \mathrm{~min} . c$, Internal tubulin staining of cell in $b$ following fixation and saponin treatment. Note that many of the surface GalC patches (arrows) are surrounded by cytoplasmic tubulin-stained structures (arrows). $d$, MBP domains in oligodendroglia that were fixed, saponintreated, and stained with anti-MBP with GAM-TRITC. $e$, Same cell in $d$ double-labeled for tubulin. Note that MBP domains (arrows) are located inside microtubular structures (arrows). Scale bar, $15 \mu \mathrm{m}$.

the final $24 \mathrm{hr}$. Again, no clear alteration of GalC synthesis was observed (data not shown).

\section{Discussion}

Continuous exposure of oligodendroglia to anti-GalC alters the shape and organization of the membrane sheets in several ways. The most obvious and dramatic change is the marked contraction of the membrane sheets. This change does not require the presence of second antibody, and it is reversible upon removal of anti-GalC. As sheet contraction occurs, the surface of the membrane is increasingly ruffled and finally becomes a mass of bulbous protrusions. The formation of these protrusions is seen with anti-sulfatide, but sheet contraction does not occur and the number of bulbous protrusions is fewer than with anti-GalC. Thus, there may be a relationship between the extent of formation of bulbous protrusions and sheet contraction. As visualized immunocytochemically, sheet contraction is preceded by alterations in organization of GalC on the membrane surface; initially surface GalC becomes patched over internal MBP domains, and there is subsequent massive redistribution of microtubules and surface GalC. The cascade of molecular events initiated by binding of anti-GalC that result in the described morphologic alterations is not yet known.

GalC is normally distributed uniformly throughout membrane sheets, and addition of anti-GalC for at least $1 \mathrm{hr}$ does not alter this distribution. However, addition of second antibody during this time period results in patching of anti-GalC:GalC complexes on membrane surfaces (Dyer and Benjamins, 1988). In this study, we have shown that following an anti-GalC exposure of $2 \mathrm{hr}$, patching can no longer be induced on membrane surfaces by addition of second antibody. It would follow that the presence or absence of patching of anti-GalC:GalC complexes upon addition of second antibody must be due to changes occurring in membrane organization of fluidity resulting from 

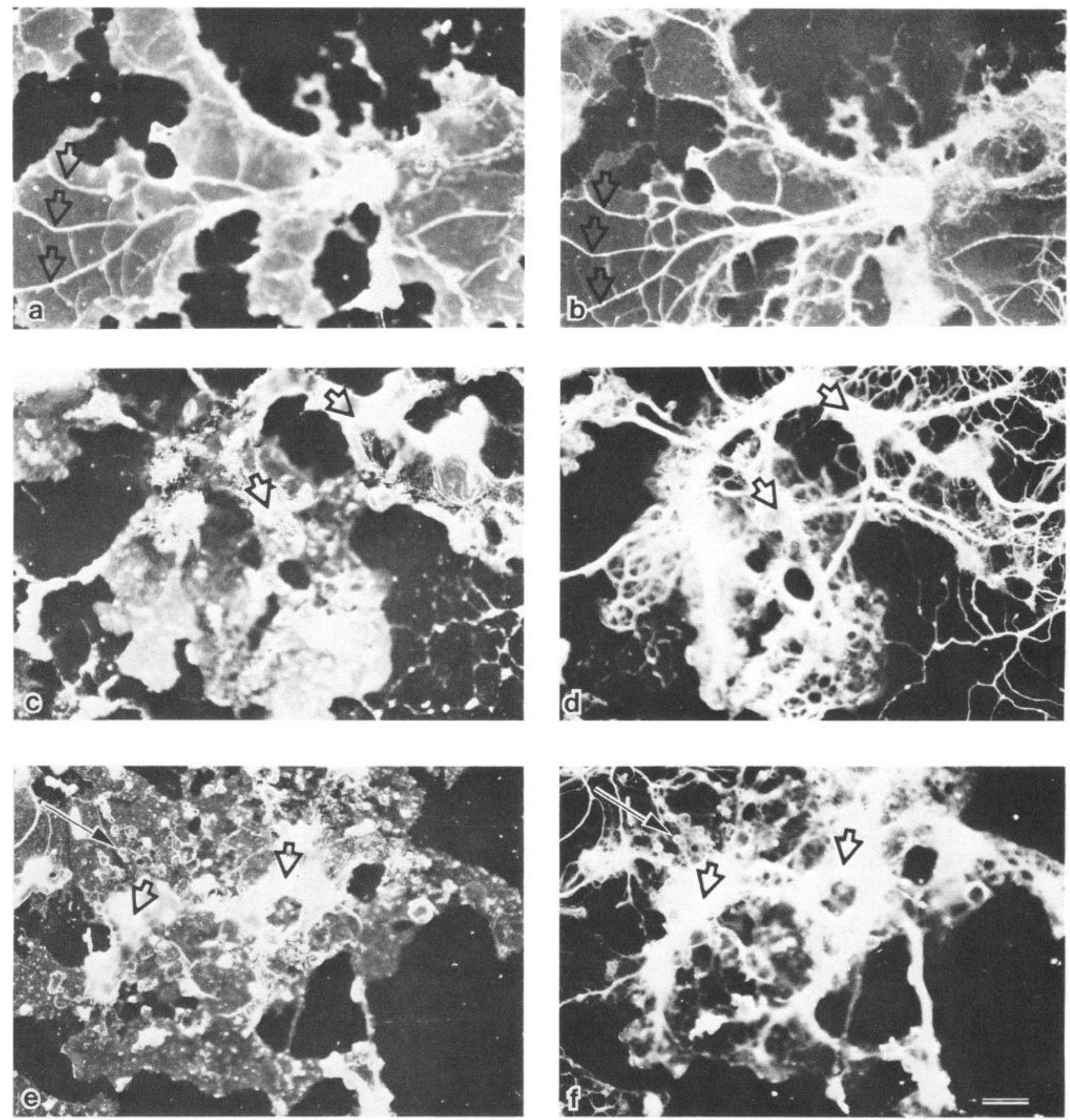

Figure 5. Alterations in underlying tubulin network in oligodendroglial membrane sheets after continuous exposure to anti-GalC. Cells were exposed to anti-GalC for $6-10 \mathrm{hr}$ followed by treatment with GAR-FITC for $15 \mathrm{~min}$. The cells were then fixed, treated with saponin, and stained for tubulin with a monoclonal IgG and GAM-TRITC. $a$ and $c$, Surface GalC staining after a $6 \mathrm{hr}$ exposure to anti-GalC. $b$ and $d$, Internal tubulin staining of cells shown in $a$ and $c$, respectively. $e$, Solidly stained membrane surface containing brightly stained rings (solid arrows) after a 10 hr exposure to anti-GalC. $f$, Internal tubulin staining of cell shown in $e$ with tubulin structures beneath the brightly stained rings of GalC (solid arrows). Note in all 3 cases that intense GalC stained areas (open arrows) are located over brightly stained microtubular structures (open arrows). Scale bar, $20 \mu \mathrm{m}$.

the anti-GalC exposure. Indeed, second antibody may be accelerating the reorganization initiated by $\mathrm{GalC}$ since preliminary evidence indicates that anti-GalC alone for $2 \mathrm{hr}$ does result in patching of GalC. Also, further evidence obtained by SEM showed that exposure to anti-GalC alone results in morphologic changes; the observed changes were the sole result of anti-GalC exposure since colloidal gold-conjugated second antibody was added subsequent to fixation. Thus, addition of second antibody allows detection of alterations in the properties of membrane sheets resulting from anti-GalC exposure.

The changes in oligodendroglial membranes due to anti-GalC: second antibody exposure parallel, to a certain extent, patching and capping in lymphocytes. Patching of numerous lymphocyte membrane components-including Ig, $\mathrm{H}-2$ antigens, $\mathrm{B}_{2}$-mi- 
Table 1. Incorporation of ${ }^{3} \mathrm{H}$-galactose into galactocerebroside in oligodendroglia exposed to anti-galactocerebroside

\begin{tabular}{lllc}
$\begin{array}{l}\text { Experi- } \\
\text { ment }\end{array}$ & $\begin{array}{l}\text { Control } \\
\text { (cpm/flask) }\end{array}$ & $\begin{array}{l}\text { +Anti-GalC } \\
\text { (cpm/flask) }\end{array}$ & $\begin{array}{l}\% \\
\text { Control }\end{array}$ \\
\hline 1 & $11,900 \pm 730$ & $11,770 \pm 2370$ & 99 \\
2 & $14,375 \pm 2375$ & $16,430 \pm 3830$ & 114
\end{tabular}

Approximately $1 \times 10^{6}$ cells (shakeoff cultures enriched in oligodendrocytes) in $25 \mathrm{~cm}^{2}$ flasks were incubated for $24 \mathrm{hr}$ with either anti-GalC or nonspecific RIgG and $100 \mu \mathrm{Ci}$ of ${ }^{3} \mathrm{H}$-galactose in $3 \mathrm{ml}$ of medium. After $24 \mathrm{hr}$, cells were trypsinized, and lipid extracts were performed on the cell pellets followed by alkaline methanolysis. The resulting lipids were run on TLC plates, and the bands of GalC were scraped from the plates and counted. Cultures were treated with nonspecific RIgG (controls) or with anti-GalC RIgG. Results are presented as cpm in GalC per flask. Values represent averages \pm ranges for duplicate flasks.

croglobulin, Thy-1 antigens, gangliosides, and haptenated lipids-has been reported (Taylor et al., 1971; Schreiner and Unanue, 1977; Schroit and Pagano, 1978; Spiegel et al., 1984). In oligodendrocytes, we observed distinct GalC patches on membrane sheets after exposure to anti-GalC and second antibody. On lymphocyte membranes, depending on the antigen, patches can coalesce into caps in a matter of minutes. Similarly, Kachar et al. (1986) reported capping of cross-linked surface antibodyGalC complexes within $30 \mathrm{~min}$ on rat oligodendrocytes with numerous motile processes. However, such short-term changes were not seen in the more mature oligodendrocytes with extended membrane sheets that we studied. Instead, alterations which may correspond to capping occurred after 6-24 hr of continuous exposure to anti-GalC. After $6 \mathrm{hr}$, a majority of membrane sheets were solidly stained with a wrinkled appearance; by scanning electron microscopy, ruffling of entire oligodendrocyte membranes was observed. By $24 \mathrm{hr}$, the membrane sheets were contracted, and entire oligodendroglial surfaces consisted of bulbous protrusions that are very similar in appearance to structures induced by ConA on T-lymphocytes (Polliack et al., 1976) and to structures present in caps induced by antiimmunoglobulin (anti-Ig) antibody on B-lymphocytes (Kamovsky and Unanue, 1978).

In our study, patches of cross-linked anti-GalC:GalC complexes were observed above normally occurring MBP domains which lie between microtubular structures in oligodendroglial membranes. A similar relationship between surface $\mathrm{GalC}$ patches and intracellular CNPase has been described (Knapp et al., 1987b). Our preliminary results support these findings and indicate that in many membrane sheets CNPase and tubulin are colocalized. Thus, in addition to tubulin and actin (Kachar et al., 1986), CNPase also appears to play a role in the cytoskeletal organization of membrane sheets (Braun et al., 1986; Reynolds et al., 1987).

In other cell types, such as lymphocytes and fibroblasts, the initial linkage of surface patches with the underlying cytoskeleton occurs via several cytoskeletal components, including $\alpha$-actinin, actin, myosin, and fodrin (Ash and Singer, 1976; Ash et al., 1977; Flanagan and Koch, 1978; Geiger and Singer, 1979; Bourguignon et al., 1985). Since we have shown that surface GalC patches are found above the normally occurring cytoplasmic MBP domains, it may be that MBP plays a cytoskeletal role in the morphologic changes observed in anti-GalC-treated oligodendrocytes. Indeed, MBP has been shown to induce in vitro polymerization of $\mathrm{G}$-actin (Dobrowolski et al., 1986) and tubulin (Modesti and Barra, 1986). The possibility that MBP plays a cytoskeletal role is further strengthened by the observation that monoclonal antibodies directed against MBP share a common antigenic determinant with an intermediate filament protein in astrocytes (Brenner et al., 1986). The nature of the association between cross-linked GalC on the surface of these membranes and MBP on the cytoplasmic face of the lipid bilayer is as yet unknown. It may be that MBP is involved in the transmission of surface membrane signals to the interior of oligodendroglia, a possibility suggested by Vartanian et al. (1986). In their system, an increase in MBP phosphorylation was observed within $24 \mathrm{hr}$ after adherence of oligodendrocytes to substratum.

Our results demonstrate that initially GalC patches and microtubular structures are not colocalized. After patching occurs, there is a loss of the fine microtubular structures normally present in oligodendroglial membrane sheets. Similarly, patch formation leads to disorganization of microtubules in anti-Ig-treated lymphocytes (Yahara and Kakimoto-Sameshima, 1978). In oligodendrocytes, a massive reorganization of tubulin was observed in many membrane sheets following a $6 \mathrm{hr}$ exposure to anti-GalC. At this time, changes analogous to capping have occurred, with intense surface antibody:GalC staining now colocalized with internal tubulin staining. While actin and other microfilament proteins have been shown to mediate the initial linkage of membrane patches with the cytoskeleton, both microfilaments and microtubules have been shown to be associated with the subsequent capping process (Gabbiani et al., 1977; Flanagan and Koch, 1978; Yahara and Kakimoto-Sameshima, 1978; Geiger and Singer, 1979). Taken together, our results suggest that the initial associaton of anti-GalC:GalC complexes with the cytoskeleton may involve MBP and that with time these surface complexes become associated with the underlying microtubular structures in a process which may be analogous to capping in lymphocytes.

We do not know whether the sheet contraction and the associated changes in organization of membrane components result from the continuous internalization and recycling of antiGalC (Dyer and Benjamins, 1988) or from some other signal initiated by anti-GalC. However, a mechanism for transmission of a signal from surface lipids to intracellular proteins can be postulated. The aggregation of cross-linked GalC molecules over MBP domains indicates the formation of distinct lipid domains in oligodendroglial membranes. Since cerebrosides have been shown to impart order to membranes (Curatolo and Nertinger, 1986), it may be that the newly formed GalC domains are highly ordered. Thus, if changes in membrane fluidity occur due to GalC patching, they may signal the long-term cytoskeletal reorganization observed in oligodendroglia, either through direct effects on MBP or indirectly via an intramembranous protein which then interacts with MBP.

It is conceivable that the dramatic morphologic changes seen in oligodendroglial membrane sheets after continuous exposure to anti-GalC may be due to changes in the lipid composition of the membranes. While we have not directly examined the composition of the oligodendroglial surface membranes, several observations indicate that no major changes are occurring in GalC content, despite extensive internalization of anti-GalC: GalC complexes. In our previous study, oligodendroglial membranes were never depleted of GalC even after $7 \mathrm{~d}$ of continuous exposure to anti-GalC; in addition, we showed that anti-GalC, presumed to be still attached to GalC, recycles back to the membrane surface after internalization (Dyer and Benjamins, 
1988). Thus, the recycling may account for the continued presence of GalC on membrane surfaces even after extended exposure to anti-GalC. In the present study, metabolism of GalC was not altered following exposure of cultures to anti-GalC for 24 or $72 \mathrm{hr}$, and loss of GalC from oligodendroglial membranes via shedding could not be detected. These results taken together strongly suggest that alterations in levels of GalC do not account for the morphologic changes occurring in these cells.

It is of interest that oligodendroglia keep up with the internalization of anti-GalC:GalC complexes in such a way that GalC is never depleted from the surface. This is in contrast to the results of Ranchst et al. (1987) with Schwann cells; in their study, GalC was depleted from the glial surface within 30 min of exposure to anti-GalC. This may be related to the fact that oligodendrocytes in culture continue to express high levels of surface GalC in the absence of axons (Mirsky et al., 1980; Dubois-Dalcq et al., 1986; Knapp et al., 1987a; Dyer and Benjamins, 1988), while Schwann cells require the presence of axons (Mirsky et al., 1980) or elevated cAMP levels (Sobue and Pleasure, 1984; Jessen et al., 1985) to maintain detectable levels of surface GalC. Differences between oligodendrocytes and Schwann cells in the recycling or degradation of GalC could also account for the observed differences in expression of surface GalC following prolonged exposure to anti-GalC.

The changes we observed may be related to the alterations in myelin structure caused by complement-depleted white matter antiserum on myelinating organ cultures (Diaz et al., 1976). The serum caused increased birefringence and doubling of periodicity between the major dense lines in myelin and the production of disorganized layers of membrane. Our results on the effects of antibodies to glycolipids on cultured uligodendroglia further demonstrate that $\mathrm{GalC}$ and sulfatide perform essential roles in the structure of membranes of myelin-producing cells. AntiGalC exposure results in the contraction of membrane sheets, the formation of bulbous protrusions on membrane surfaces, and the dramatic reorganization of the underlying cytoskeleton. Exposure to anti-sulfatide leads to similar changes, with the exception of sheet contraction. We do not know if the inability of anti-sulfatide to produce sheet contraction is due to differences in function between these 2 glycolipids or to differences in the class of antibody, IgG or IgM. While signal transmission via surface proteins is well known, the ability of surface glycolipids to function in this manner has been studied in less detail. One notable example is that of interaction of cholera toxin with GM1 ganglioside (Fishman, 1982).

We have presented evidence that the appropriate distribution of glycolipids within the surface bilayer appears to be essential for the normal formation and maintenance of membrane by myelin-producing cells. More importantly, our results provide direct evidence that interaction between surface glycolipids and external ligands can initiate a sequence of events leading to dramatic changes in the organization of both surface and cytoplasmic structures within oligodendroglial membrane sheets.

\section{References}

Ash, J. F., and S. J. Singer (1976) Concanavalin-A-induced transmembrane linkage of concanavalin A surface receptors to intracellular myosin-containing filaments. J. Cell Biol. 73: 4575-4579.

Ash, J. F., D. Louvard, and S. J. Singer (1977) Antibody-induced linkages of plasma membrane proteins to intracellular actomyosincontaining filaments in cultured fibroblasts. J. Cell Biol. 74: 5584 5588.
Barbarese, E., and S. E. Pfeiffer (1981) Developmental regulation of myelin basic protein in dispersed cultures. Proc. Natl. Acad. Sci. USA 78: 1953-1957.

Benjamins, J. A., R. E. Callahan, I. E. Montgomery, D. M. Studzinski, and C. A. Dyer (1987) Production and characterization of high titer antibodies to galactocerebroside. J. Neuroimmunol. 14: 325-338.

Bottenstein, J. E. (1986) Growth requirements in vitro of oligodendrocyte cell lines and neonatal rat brain oligodendrocytes. Proc. Natl. Acad. Sci. USA 83: 1955-1959.

Bourguignon, L. Y. W., S. J. Suchard, M. L. Nagpal, and J. R. Glenney, $\mathrm{Jr}$. (1985) A T-lymphoma transmembrane glycoprotein (gp 180) is linked to the cytoskeletal protein, fodrin. J. Cell Biol. 101: 477-487.

Bradel, E. J., and F. P. Prince (1983) Cultured neonatal rat oligodendrocytes elaborate myelin membrane in the absence of neurons. J. Neurosci. Res. 9: 381-392.

Braun, P. E., A. M. Edwards, and P. M. Pereyra (1986) New aspects of a membrane skeleton in CNS myelin. Trans. Am. Soc. Neurochem. 17: 256 (abstr.).

Brenner, T., R. P. Lisak, A. Rostami, D. E. Pleasure, and D. H. Silberberg (1986) Astrocytes, oligodendrocytes, and Schwann cells share a common antigenic determinate that cross-reacts with myelin basic protein: Identification with monoclonal antibody. J. Neurosci. 6: 19251933.

Curatolo, W., and L. J. Neuringer (1986) The effects of cerebrosides on model membrane shape. J. Biol. Chem. 261: 17177-17182.

Diaz, M., M. B. Bornstein, and C. J. Raine (1978) Disorganization of myelinogenesis in tissue culture by anti-CNS antiserum. Brain Res. 154: 231-239.

Dobrowolski, Z., H. Osinska, M. Mossakowska, and B. Barylko (1986) $\mathrm{Ca}^{2+}$-calmodulin-dependent polymerization of actin by myelin basic protein. Eur. J. Cell Biol. 42: 17-26.

Dubois-Dalcq, M., T. Behar, L. Iludson, and R. A. Lazzarini (1986) Emergence of three myelin proteins in oligodendrocytes cultured without neurons. J. Cell Biol. 102: 384-392.

Dyer, C. A., and J. A. Benjamins (1988) Redistribution and internalization of antibodies to galactocerebroside by oligodendroglia. J. Neurosci. 8: 883-891.

Fishman, P. H. (1982) Role of membrane gangliosides in the binding and action of bacterial toxins. J. Membr. Biol. 69: 85-97.

Flanagan, J., and G. L. E. Koch (1978) Cross-linked surface Ig attaches to actin. Nature $273: 278-281$.

Folch, J., M. Lees, and G. H. Sloane-Stanley (1957) A simple method for the isolation and purification of total lipids from animal tissues. J. Biol. Chem. 226: 497-507.

Gabbiani, G., C. Lees, A. Zumbe, and P. Vassalli (1977) Actin and tubulin co-cap with surfacc immunoglobulins in mouse B lymphocytes. Nature 269: 697-698.

Geiger, B., and S. J. Singer (1979) The participation of $\alpha$-actinin in the capping of cell membrane components. Cell 16: 213-222.

Jessen, K. R., L. Morgan, M. Brammer, and R. Mirsky (1985) Galactocerebroside is expressed by non-myelin forming Schwann cells in situ. J. Cell Biol. 101: 1135-1143.

Kachar, B., T. Behar, and M. Dubois-Dalcq (1986) Cell shape and motility of oligodendrocytes cultured without neurons. Cell Tissue Res. 244: 27-38.

Karnovsky, M. J., and E. R. Unanue (1978) Cell surface changes in capping studied by correlated fluorescence and scanning electron microscopy. Lab. Invest. 39: 554-564.

Kishimoto, Y., and N. S. Radin (1965) Developing rat brain: Changes in cholestrol, galactolipids, and the individual fatty acids of gangliosides and glycerophosphatides. J. Lipid Res. 6: 525.

Knapp, P. E., W. P. Bartlett, and R. P. Skoff (1987a) Cultured oligodendrocytes mimic in vivo phenotypic characteristics: Cell shape, expression of myelin specific antigens and membrane production. Dev. Biol. 120: 356-365.

Knapp, P. E., R. P. Skoff, and T. J. Sprinkle (1987b) Oligodendrocyte development in vitro: Double-label immunostaining for galactocerebroside and 2',3'-cyclic nucleotide 3'-phosphohydrolase. J. Neurochem. 48S:S30.

Lehrer, G. M., S. Maker, D. J. Silides, C. Weiss, and M. B. Bornstein (1979) Stimulation of myelin lipid synthesis in vitro by white matter antiserum in absence of complement. Brain Res. 172: 557-560.

Lowry, O. H., N. J. Rosebrough, A. L. Farr, and R. J. Randall (1951) Protein measurement with the Folin phenol reagent. J. Biol. Chem. 193: $265-275$. 
Meller, K., and M. Waelsch (1984) Cyclic morphological changes of glial cell in long-term cultures of rat brain. J. Neurocytol. 13: 29-47.

Mirsky, R., J. Winter, E. R. Abney, R. M. Pruss, J. Gavrilovic, and M. C. Raff (1980) Myelin-specific proteins and glycolipids in rat schwann cells and oligodendrocytes in culture. J. Cell Biol. 84: 483-494.

Modesti, N. M., and H. S. Barra (1986) The interaction of myelin basic protein with tubulin and the inhibition of tubulin carboxypeptidase activity. Biochem. Biophys. Res. Commun. 136: 482-489.

Pfeiffer, S. E. (1984) Oligodendrocyte development in culture systems. In Oligodendroglia, W. T. Norton, ed., pp. 233-298, Plenum, New York.

Poduslo, S. E., R. Curbeam, K. Miller, and P. Reier (1985) Purification and characterization of cultures of oligodendroglia from rat brain. $\mathbf{J}$. Neurosci. Res. 14: 433-447.

Polliack, A., M. Froimovici, S. Frankenburg, and I. Gery (1976) Altered surface morphology of concanavalin: A transformed thymic lymphocyte as seen by scanning electron microscopy. Biomedicine 24: 389-395.

Ranchst, B., P. M. Wood, and R. P. Bunge (1987) Inhibition of in vitro peripheral myelin formation by monoclonal anti-galactocerebroside. J. Neurosci. 7: 2936-2947.

Reynolds, R., E. Carey, and N. Horschkowitz (1987) Differential localization of MBP and CNP in a myelin-like membrane produced by oligodendrocytes in culture. J. Neurochem. 48: S179.

Rome, L. H., P. N. Bullock, F. Chiappelli, M. Cardwell, A. M. Adinolfi, and D. Swanson (1986) Synthesis of a myelin-like membrane by oligodendrocytes in culture. J. Neurosci. Res. 15: 49-65.

Sarlieve, L. L., G. S. Rao, G. LeM. Campbell, and R. A. Pieringer (1980) Investigations on myelination in vitro: Biochemical and morphological changes in cultures of dissociated brain cells from embryonic mice. Brain Res. 189: 79-90.
Schreiner, G. F., and E. R. Unanue (1977) Capping and the lymphocyte: Models for membrane reorganization. J. Immunol. 119: 15491551.

Schroit, A. J., and R. E. Pagano (1978) Introduction of antigenic phospholipids into the plasma membrane of mammalian cells: Organization and antibody-induced lipid redistribution. Cell Biol. 75 . $5529-5533$

Sobue, G., and D. Pleasure (1984) Schwann cell galactocerebroside induced by derivatives of adenosine $3^{\prime}, 5^{\prime}$-monophosphate. Science 224: $72-74$

Spiegel, S., S. Kassis, M. Wilchek, and P. H. Fishman (1984) Direct visualization of redistribution and capping of fluorescent gangliosides on lymphocytes. J. Cell Biol. 99: 1575-1581.

Suzumura, A., S. Bhat, P. A. Eccleston, R. P. Lisak, and D. H. Silberberg (1984) The isolation and long-term culture of oligodendrocytes from newborn mouse brain. Brain Res. 324: 379-383.

Szuchet, S., K. Stefansson, R. L. Wollman, G. Dawson, and B. G. W. Arnason (1980) Maintenance of isolated oligodendrocytes in longterm culture. Brain Res. 200: 151-164.

Taylor, R. B., W. P. H. Duffus, M. C. Raff, and S. de Petris (1971) Redistribution and pinocylosis of lymphocyte surface immunoglobulin molecules induced by anti-immunoglobulin antibody. Nature [New Biol.] 233: 225-229.

Vartanian, T., S. Szuchet, G. Dawson, and A. T. Campagnoni (1986) Oligodendrocyte adhesion activates protein kinase C-mediated phosphorylation of myelin basic protein. Science 234: 1395-1398.

Yahara, I., and F. Kakimoto-Sameshima (1978) Microtubule organization of lymphocytes and its modulation by patch and cap formation. Cell 15: 251-259. 